\title{
A PERDA DO MUNDO
}

\author{
José ARTHUR GIANNOTTI
}

\section{RESUMO}

Estamos diante de um paradoxo: vivemos num mundo globalizado, em que os acontecimentos podem ser apresentados em tempo real, mas não logram se armar numa imagem de mundo que nos conduza a ele como nossa morada. Neste artigo, pergunta-se se haveria algum rebatimento entre o funcionamento atual do sistema capitalista e essa experiência de falta do mundo que nos persegue no cotidiano.

PALAVRAS-CHAVE: capitalismo; filosofia; lógica; globalização.

\section{SUMMARY}

We face a paradox: we live in the age of globalization, in which events can be presented in real time, but they're unable to structure themselves in an image of the world that welcomes us to it as our shelter. In this article, it's asked if there would be a connection between the way capitalism functions and this experience of absence of the world that stalks us in our daily life.

KEYWORDS: capitalism; philosophy; logic; globalization.

[1] A primeira versão deste ensaio serviu de base para uma conferência, em maio de 2008 , para a APEC (Associação dos Pesquisadores e Estudantes Brasileiros da Catalunha).
I.

Nos meados do século XIX, quando ciência e tecnologia iniciaram seu desenvolvimento exponencial, ainda era impossível imaginar as transformações que elas provocariam no pensamento, na vida cotidiana e nas condições de nossa sobrevivência. Inclusive que a distância entre elas se estreitasse de tal maneira que já se fala em tecnociência, porquanto certos resultados tecnológicos às vezes são tão surpreendentes que exigem novas teorias para serem entendidos. Muitas vezes hoje ciências parecem ficções científicas, diferentes, porém, dos romances de Júlio Verne, que são dos anos 60 e 70 do Oitocentos. Nestes descrevem-se viagens que se tornam extraordinárias na medida em que seus personagens passam a ter à disposição máquinas fabulosas, as quais, contudo, a despeito de toda sofisticação, continuam sendo balões, submarinos etc.; em resumo, objetos do cotidiano que teriam sido construídos com a ajuda de procedimentos técnicos apenas mais sofisticados e potentes daqueles já conhecidos. Refletiam, em suma, a fase da manufatura do desenvolvimento tecnológico. Hoje, em contrapartida, não tem cabimento afirmar que a Demoiselle de Santos Dumont seja um objeto da mesma espécie que uma nave espacial. Ainda que ambos conservem o nome comum de nave, eles voam graças a princípios radicalmente diversos, um é objeto mecânico engenhoso, outro é eletrônico, cibernético, tendo suas partes articuladas por redes de informação. 
Mas aquilo que parecia destinado a transformar unicamente pedaços do mundo cotidiano mudou completamente nossa experiência de mundo. Alteraram-se as relações que mantemos conosco, com os outros e com a natureza. Nesse plano o desencantamento foi profundo. Se a psicanálise ainda recorre a procedimentos simbólicos, hoje preferimos controlar nossos corpos e nossas mentes mediante pílulas, exames sofisticadíssimos e aparelhos extraordinários. Tratamos quimicamente nossas depressões, nossas angústias, nossas perdas, as ansiedades da espera. Além do mais, tanto os lazeres individuais como os coletivos são mediados por aparelhos sofisticados. A internet nos conecta com pessoas as mais diversas, distribuídas nas mais longínquas partes do globo e coloca à nossa disposição informações e conhecimentos de toda espécie. Por fim, se, de um lado, a natureza opõe seus limites à devastadora exploração capitalista, de outro, ela surge como fonte de tecnologias prontas, como mostra a importância da biodiversidade para a descoberta de novas drogas.

Tudo isso nos exterioriza de maneira até então inimaginável. Não é o que já se percebe quando observamos as mudanças provocadas pelo telefone celular nas técnicas da fala e do corpo? Expressamos em público o que antes só dizíamos na intimidade, gesticulamos sozinhos como se estivéssemos em frente de outros e a nova geração se "torpedeia" usando uma linguagem cifrada que só ela entende. A cada momento somos puxados para fora, participamos de redes e de correntes cujos horizontes ignoramos. Estamos sempre juntos, mas quase sempre sozinhos.

Tudo isso revoluciona nossos modos de pensar. O Ocidente começou quando aprendemos a dominar o discurso friccionando significações contra significações de tal modo que o pensamento ganhasse precisão e universalidade capazes de capturar os princípios das coisas. Feito esse percurso, era possível então descer até às experiências das próprias coisas, agora armadas pelo pensamento num mundo inteligível, natural e humano. De ambos os lados do processo de falar e de pensar se situavam duas presenças, a presença das idéias, a visibilidade máxima, e a presença empírica dos fatos articulando sensações e imagens. Mesmo quando se considera o pensar como logos que se volta a si mesmo percorrendo as paradas do espírito, ainda está presente o visível, o lugar onde o espírito se mostra. Lembremo-nos da Fenomenologia do espírito de Hegel.

Não mais tratamos, entretanto, imagem e pensamento desse modo. Não precisamos da imaginação para tornar presentes todos os lados de um cubo, pois um pequeno aparelho estereográfico nos apresenta esse sólido conforme gira seus perfis. Para nós o cubo pode deixar de ser aquela peça sobre a mesa para se tornar objeto sistematicamente controlável segundo os diversos ângulos de sua 
aparição. E quase sempre junto das coisas residem suas imagens. Pensar tende a ser confundido com modelar, construir imagens do real, simbólicas; discursivas ou simplesmente plásticas. Imagens simbólicas servindo de trampolim para controlaro real enquanto ele se conforma às variáveis do modelo.É de notar, num plano mais imediato, que as exposições tradicionalmente discursivas, como a aula e a conferência, agora costumam se apoiar em gráficos e imagens; no mínimo o orador acompanha suas palavras com suas próprias frases projetadas numa tela. Nos tempos em que se escrevia à mão, cada palavra era desenhada por traços regulados, produto de refinado controle dos dedos, enquanto hoje, diante da tela do monitor, as letras e as palavras se formam por toques descontínuos e decididos, que nada têm a ver com a coisa escrita, ou melhor, nem mais ela é coisa, apenas traços numa tela luminosa. Nem mesmo Walter Benjamin, que percebera como a nova técnica liberaria a escrita do traçado da mão, poderia imaginar que ela poderia surgir como se fosse diretamente dos gestos.

II.

Até os meados do século passado o mundo ainda poderia ser totalizado numa rede de imagens. No século XIX ele foi considerado, por Schopenhauer, como minha representação, o fluxo de imagens me passando pelo espírito, a despeito de ele mesmo ter a vontade como fundamento. No Tractatus, Wittgenstein leva ao limite esse papel coordenador da imagem. Pensa a linguagem como imagem do mundo, porquanto cada proposição com sentido desenharia uma Bild, uma figuração, de um estado de coisa. Dessa perspectiva, o mundo vem a ser a totalidade dos fatos, não das coisas; tudo aquilo que pode ser afigurado, ligando-se entre si em conúbio com as imagens discursivas. Mais tarde ele mesmo comentou seu engano ao supor que todos os enunciados poderiam ser redutíveis a uma única e simples forma lógica, servindo de base para compor enunciados complexos graças a conectivos sem sentido, meramente combinatórios de valores de verdade. Reportando-se ao Tractatus, comenta:

[2] Wittgenstein, Ludwig. Philosophische Untersuchungen, \# 96. Schriften 1. Frankfurt: Suhrkamp, 1996 (Bibliothek SuhrKamp).
O pensar, a linguagem, aparece-nos então como o correlato singular, a imagem, do mundo. Os conceitos: proposição, linguagem, pensar, mundo encontram-se numa série, um atrás do outro, um equivalente ao outro. (Mas para que devemos usar agora essas palavras? Falta o jogo de linguagem na qual são empregadas ${ }^{2}$.)

Descobre que as palavras, antes de seencadearem nessa seqüência, se encastoam em esquemas práticos nos quais ganham suas respectivas densidades significativas. 
Ora, desintegrada a seqüência "proposição, linguagem, pensar, mundo", o dizer e o pensar passam a ser considerados num contexto pragmático, como um jogo em que os objetos denotados se individualizam para a linguagem no contexto de práticas aprendidas. A ontologia, dirá Wittgenstein, está inscrita na linguagem, mas por isso mesmo os objetos são dados em complexos. Linguagem num sentido muito amplo, pois é possível então levar em conta jogos de linguagem nãoverbais, objetos que se articulam em signos mediante uma gramática definida. E, desse ponto de vista, o que importa para o funcionamento da linguagem não é tanto o mundo do qual ela fala, mas a imagem dele demarcando as travações práticas e lingüísticas que permitem os atos de significar e se comunicar. Uma imagem de mundo aparece então como pressuposto transcendental das condições de significação e entendimento. No entanto, como não existe uma única linguagem, um único continente das significações possíveis, esta imagem do mundo, na sua pressuposição de condição de existência dos jogos de linguagem cotidianos e de outros sistemas simbólicos, não pode se apresentarenquadrada em parâmetros indeformáveis, porquanto ela se manifesta no emaranhado das práticas lingüísticas cujos pressupostos podem ser tematizados em sistemas e vice-versa. Trata-se de um transcendental que pode se converter em tema, assim como o tema pode se converter em transcendental. Desse ponto de vista não se pode falar de um terreno comum, de um mundo da vida como fonte das significações e dos sistemas simbólicos, porquanto sistema e imagem de mundo se situam estrategicamente conforme as necessidades e os projetos das práticas humanas significativas. Ora, desse ponto de vista cabe perguntar se o desvairado avanço da tecnociência contemporânea e a forma social do uso de seus produtos não terminam trincando esse jogo da imagem do mundo, da linguagem e do próprio mundo de que ela fala.

\section{III.}

Vale a pena então retomar as observações iniciais a respeito das mudanças em curso do uso das imagens, por conseguinte de seus sentidos. Para isso o cinema nos fornece exemplos privilegiados. No meio do fluxo de uma avalanche de imagens articuladas em narrativas de consumo imediato, armadas para o entretenimento massificado, articula-se a meu ver a arte mais significativa do século XX, pois ela pensa tanto os problemas cotidianos como os enigmas da existência humana no plano mais radical das melhores belas-artes. Graças a um tratamento altamente sofisticado da imagem, propiciado por um desenvolvimento tecnológico contínuo ao longo do século XX, capaz de associá-la à palavra eà música, assim como de criar situações especialíssimas fora do enquadramento determinado pelas ciências naturais, o cinema se transformou numa forma inédita de pensar. 
Notável é que desenvolve linhas paralelas de pensamento, que às vezes se cruzam e se separam criando um fluxo de imagens, palavras e de sons que apresentam situações como se fossem reais, mas sob um aspecto especialíssimo, porquanto muitas vezes mostram acontecendo o que não pode acontecer. Reflete, além do mais, sobre as condições desse narrar, inclusive sobre as peculiaridades do material imagético utilizado. A literatura sempre explorou as duas dimensões do dito e do dizer; em particular a poesia lírica experimentou consonâncias e dissonâncias da imagem sonora capazes de evocar sentimentos delicados e indefinidos. Mas nunca criou uma situação percebida e pensada como se fosse real. E o teatro, por sua vez, sempre lidou com a diferença entre o palco e a platéia, o fingido e o que está ali, mesmo quando personagens saem à procura de um autor. Em contrapartida, a bidimensionalidade de uma tela brilhante que se abre em janela dissolveu a platéia no escuro, jogando o espectador num ponto de vista do qual tende a olhar o que aconteceria no mundo sem se olhar. Além do mais, se tornou capaz de montar ao mesmo tempo diferentes linhas significativas de imagens, correndo paralelas ou se cruzando ou se desfazendo: a visão panorâmica e sem cortes do cenário onde a trama se desenvolverá, o percurso de um carro, o encontro casual de duas pessoas, o barulho do veículo e o silêncio delas - sempre linhas construidas a partir de aspectos cuidadosamente escolhidos -, de sorte que apresenta significados cruzados como se as coisas, os objetos, as situações e as pessoas estivessem nelas mesmas desafiando suas identidades e diferenças. Torna assim presentes situações imaginadas que podem se apresentar mais reais assim como mais falsas do que os acontecimentos do cotidiano. As imagens se potencializam de modo muito mais realista do que aquela potência criada pelo retrato cubista de uma natureza-morta, em que os objetos apresentam perfis que nunca poderiam se dar juntos, acentuando, porém, a diversidade das linhas discursivas.

Para tornar palpável sua teoria das idéias e a forma de educação que ela requeria, Platão inventou o mito da caverna. Os seres humanos estariam acorrentados de tal forma que só poderiam ver o fundo dessa caverna e as imagens projetadas nele. Um longo trabalho dianoético, isto é, de pensamento dialogal, permitiria que alguns dos mais tenazes e corajosos de seus habitantes se voltassem para contemplar o fogo, a luz divina, que a iluminava. Cabia a eles, então, precisamente porque esse trabalho havia sido realizado dialogicamente, na dependência dos outros, retornar à antiga convivência para ensinar o verdadeiro caminho da verdade. Esse caminho que vai da aparência ao verdadeiramente real e retorna para o cotidiano aparente explode no cinema, na medida em que o mais aparente se mostra ele mesmo o mais real ou o mais falso. Se, 
de um lado, ele perde a paciência dos conceitos, de outro, explode nos olhos pensamentos nem sempre verbais. Podemos acompanhar, por exemplo, todos os meandros da vida de um personagem concomitantemente em suas várias dimensões e com tal senso de realidade que a mimese desaparece como elemento constitutivo. É como se estivéssemos debruçados sobre uma janela espiando a casa vizinha, mais real do que a sala escura onde estamos. Em geral o cinema põe o mundo. Mas pode ocorrer que o personagem principal perceba que sua vida se desenrolara num cenário, como acontece nesses horríveis reality shows, ou no filme mediano de Peter Weir, O show de Truman: toda a cidade onde a trama se desenvolve se mostra, no final, enorme cenário onde o personagem viveu seu drama real e fictício.

Esse fatiar da totalidade do real foi magnificamente explorado por um filme de Woody Allen, A rosa púrpura do Cairo, que mostra um personagem fugindo do retângulo da tela e passando a viver numa realidade representada como se esta fosse o mundo real. Agora a imagem na tela apresenta uma tela da qual escapa uma pessoa para viver a estranheza do mundo. Por certo toda grande arte engole o apreciador, faz com que ele se esqueça de si mesmo no momento em que ele é mais ele mesmo, porquanto explora com seus próprios meios os mistérios que o artista deixou na coisa. O observador cresce na medida em que se entrega aos traços de pensamento depositado no objeto-imagem, alimenta sua autonomia deixando-se levar pelo tratamento da imagem oferecida pelo artista. O cinema, em compensação, apresenta situações num mundo que engole o observador sendo capaz de voltar a ser ele mesmo apenas no final do filme. Ainda quando não alcança o nível das belas-artes, a sala escura apresenta um fluxo de imagens como se fosse um mundo. E o grande cinema, seguindo uma tendência, comum na arte moderna, de refletir sobre si mesma, fatia os mundos em planos nem sempre coincidentes. Um bom exemplo disso é o filme Mundo, de Jia Zhangke, que narra a aventura de artistas que trabalham num parque temático, instalado em Pequim, chamado "mundo". Um aglomerado kitsch reproduzindo ilustres monumentos espalhados pelo mundo serve de cenário para comentar o mundo fechado da atual sociedade chinesa pregada num regime autoritário.

O que importa ressaltar nesses filmes? Imagens que se integram num mundo que, por sua vez, se integra noutro e assim por diante. Mas não é por isso que desenham um universo formado por círculos concêntricos, pelo contrário, um personagem escapa de um mundo para habitar outro, ou vive num mundo falso que não é mundo para o mundo exterior que, por sua vez, não se apresenta como mundo. Estamos muito longe do universo em que se trava a guerra das estrelas 
que, a despeito de suas múltiplas dimensões, ainda forma um todo capaz de ser governado pelo poder central do Bem ou do Mal. Tudo se passa como se depois de desmontar uma daquelas bonecas russas, cada uma contendo em si outra boneca menor, nos víssemos incapazes de remontá-la, porque as bonecas incisas cresceram e perderam as proporções devidas para serem embutidas umas nas outras. Por toda parte vemos, pois, mundos cruzando mundos, assinalando como a idéia de mundo se multiplica e se torna reflexiva, perdendo assim seu caráter de todo global articulado.

IV.

Em que medida o cinema nos apresenta uma dificuldade com a qual temos de lidar cotidianamente? Tudo parece indicar que estamos vivendo processos de globalização - do capital, do circuito das notícias, da produção artística e assim por diante - sem que neles possamos encontrar um lugar onde pudéssemos habitar. Não estou me referindo a cidades inabitáveis como São Paulo ou Cidade do México. Nelas a comunicação continua instantânea, o que acontece numa parte da cidade reflete-se em todas as outras partes, mas o esforço é enorme para que se possa conviver, ocupar juntos um espaço dominado reflexivamente, graças a uma interação recíproca, muito custosa embora ainda possível. Refiro-me a uma experiência mais radical. Parece-me que estamos diante do paradoxo de vivermos num mundo globalizado, em que os acontecimentos podem ser apresentados em tempo real, mas não logram se armar numa imagem de mundo que nos conduza a ele como nossa morada.

V.

Mas, no final das contas, o que entendemos por "mundo"? À primeira vista essa palavra denota tudo o que acontece. No que consiste, porém, essa totalização? Aqui está a questão: o que "mundo" significa depende de como se costura esse processo de totalização, vale dizer, de como essa palavra se conecta em determinados jogos de linguagem que lhe confiram referência. Falamos cotidianamente no mundo significando as coisas e os processos que ambientam os seres humanos, ou ainda no mundo submarino ou o mundo do crime e assim por diante, sempre querendo dizer um todo em que "coisas" acontecem segundo uma linhagem.

Cada filosofia refina esse ponto de vista totalizante. Já lembramos que Schopenhauer pôde falar no mundo como vontade e representação na medida em que pressupunha o eu se identificando ao fluxo da representação e dos atos voluntários. Wittgenstein pôde abrir o Tractatus afirmando que "O mundo é tudo o que é o caso (was der Fall ist)" porque já pensava a proposição como figuração, imagem (Bild), de 
um estado de coisa, de sorte que o fato, o que acontece, já poderia ser entendido como caso da regra afigurante. E para assegurar que esses casos formassem um todo, foi-lhe preciso indicar que a linguagem afigurando o que acontece e o que não acontece no quadro de um espaço lógico estava pressupondo um eu transcendental, uma perspectiva fora do mundo que faz do mundo o meu mundo.

No entanto, foi a fenomenologia que trouxe para o vocabulário filosófico contemporâneo o conceito de mundo como um problema de todos os dias. Insistindo no caráter intencional da consciência, Husserl considerou possível pôr entre parênteses tudo o que foi intencionado, o mundo, como se ele fosse apenas apresentado como o outro lado dos atos conscientes. Mas essa epochê não o impediu de insistir nos laços significativos valendo entre os conteúdos desses atos. Minha mesa existe diante de mim, cheia de livros, canetas, papéis e outros objetos, tendo a cadeira ao lado onde me sento, que é minha mas também da mesa. Todas essas coisas reportando-se entre si pelos sentidos que adquirem nesse contexto prático. E nele, nesse mundo da vida (Lebenswelt), encontrar-se-iam as matrizes dos sistemas simbólicos. A geometria não retiraria dele as bases de seus conceitos? No que consiste, porém, esse "retirar"?

Seriam possíveis intuições desse mundo independentemente da gramática da linguagem que fala dele? A palavra "mundo" é equívoca, visto que seu sentido se conforma segundo o modo pelo qual os acontecimentos são alinhavados num todo. E tudo indica que esse travejamento é histórico, pelo menos ele tem sido pensado de diversas maneiras. Obviamente dessa equivocidade não escapa o conceito de mundo da vida (Lebenswelt), de sorte que, antes da descrição fenomenológica deste terreno significante donde brotariam as significações, sobretudo aquelas verbais, cabe analisar o contexto de seu sentido, vale dizer, os jogos de linguagem em que a palavra "mundo" se encastoa. Mais do que uma análise fenomenológica, impõe-se antes de tudo uma descrição de jogos de linguagem, isto é, uma análise lógica. Eesta análise só pode ser feita na base de exemplos.

No entanto, posta a equivocidade da palavra "mundo", e com ela todas as imagens a ela associadas, não é por isso que os vários sentidos estariam completamente separados entre si, átomos isolados de linguagens discretas. Os seres humanos continuam a falar na equivocidade, mas para falar eles precisam existir praticamente. É desta prática presente, mas igualmente desta linguagem equívoca que é necessário partir, já que os seres humanos sobrevivem falando, se entendendo e se desentendendo. Ora, essa existência humana, seja qual for seu significado, depende de várias atividades que a reponham, de condições de existência que não estão diretamente ligadas às gramáticas dessas práticas. Uma delas é um sistema produtivo responsável por sua exis- 
tência biológica e social. Não se tome esse sistema como transcendental, mas tão-só como uma condição de existência entre outras, prática simbólica e interativa acompanhando outras práticas.

VI.

Esse sistema é tecido por atos de trabalho. Como eles se enlaçam? Costuma-se ligá-los por uma racionalidade particular, aquela que, dado um fim, cuida dos meios para obtê-lo, em resumo, a racionalidade técnica. Mas como isolá-la da interação dos seres humanos entre si? É possível trabalhar sozinho, mas desde que o produto se insira num sistema produtivo, o ato de trabalho passa a ser dependente de, no mínimo, relações de propriedade, que impedem que o produto possa ser apropriado porqualquerum. Deixemos deladoo conceitoglobalizante de razão, simplesmente porque cada filósofo o pensa à sua maneira, na dependência,em particular, de como pensa as lógicas formais e os modos de experiência. Quando se estudam relações sociais significativas e interativas é preciso ter todo o cuidado para não subsumir determinados esquemas de conduta a uma única forma de racionalidade que, como acontece muitas vezes, retira dele peculiaridades características de seu modo de ser. Isso é freqüente no pensamento contemporâneo, quando, por exemplo, movimentos sociais são concebidos como luta por direitos que, uma vez alcançados e institucionalizados, passariam a ser aplicados como o selo deixa sua marca na cera, o ferro em brasa, uma assinatura no couro do boi. Ou ainda quando o estudioso de políticas públicas desenha um plano que só poderia ser aplicado por um órgão estatal como se este fosse representante da ordem racional das coisas, em suma, como se já não fosse político. Tudo se passaria como se atos de seguiruma regra fossem conduzidos por imagens dessa regra, desse critério, como se eles próprios não pudessem criar visgos e barreiras ao seu bom processamento do que pretendem fazer. Os procedimentos de racionalizar, contudo, estariam sempre imunes às fintas dos ardis das razões?

O conceito marxista de modo de produção nos conduz a um universo em que o seguir a regra não cria no real a imagem dela. Vale a pena, então retomá-lo, cuidando, porém, para não cair no abuso dos economistas e sociólogos dos anos 1960, que o transformaram num passe-partout enquadrando qualquer modo de coletivização dos atos de trabalho. Além disso, estou convencido de que qualquer sociedade necessita manter determinado metabolismo com a natureza, sendo que este há de obedecer a formas particulares de coletivização dos atos produtivos. Importa desde já lembrar que esses atos se coordenam num processo reflexionante de produção, distribuição, troca e consumo, que se repõe dando corpo a uma certa intenção prática historicamente determinada. É assim que atos de trabalho se articularam, por 
exemplo, para produzir e reproduzir uma riqueza social responsável por assegurar e prefigurar cidades-Estados politicamente autônomas, as póleis, embora mergulhadas num fluxo comercial, como aconteceu no Mediterrâneo durante a Antiguidade clássica. Mas o exemplo que mais interessa é nosso, o modo de produção capitalista, em que todos os fatores do processo produtivo se configuram como mercadoria, sendo que o valor agregado da mercadoria inicial vem a ser reposto e aumentado, isto é, como capital.

O que tem a ver a existência do modo de produção capitalista com a experiência do mundo? Nada, se continuarmos a pensá-lo como matriz de outros sistemas práticos significantes, infra-estrutura ancorando superestruturas, desenho inscrito na terra servindo de imagem inicial para os jogos de espelho de outras práticas sociais e culturais. Durante anos o marxismo pensou as superestruturas sendo fundadas nas relações sociais de produção mobilizando forças produtivas correspondentes. Já lembramos que igualmente a fenomenologia fez do mundo da vida o terreno de onde as práticas coletivas retiravam seus sistemas simbólicos. Parece-me, contudo, que o desenvolvimento contemporâneo da filosofia da lógica, a partir das descobertas dos anos 1930 e das reflexões do segundo Wittgenstein, termina pondo em xeque a própria idéia de fundamento. É natural que se escrevêssemos unicamente com pincéis nossa geometria pudesse ser diferente. Mas entre essa prática da escrita e os conceitos armados num sistema graças a conexões necessárias internas se abre uma cesura, uma invenção, impedindo que o desenho da prática determine a figura dos conceitos. Essa prática é condição de existência de outros sistemas simbólicos, mas suas regras não fazem parte do travejamento simbólico deles. É como um tabuleiro de xadrez que pode ser feito de materiais e tamanhos diferentes, mas que não pode deixar de combinar quadrados numa determinada proporção. Desse ponto de vista, haveria algum rebatimento entre o funcionamento atual do sistema capitalista eessa experiência de falta do mundo que nos persegue no cotidiano?

Marx nos lembra que o modo de produção capitalista se mantém graças a duas histórias. A primeira mostra o desenvolvimento das categorias conforme elas próprias vão se repondo. Essa história categorial se inicia com a troca de mercadorias $(\mathrm{M}=\mathrm{M})$ e se expande até o capital se apresentar sob três formas básicas: o capital gerando lucro, a propriedade privada da terra gerando renda e o trabalho gerando salário. Os juros são os lucros sob a forma mais alienada. A segunda história é aquela que descreve como essas estruturações se instalam em cada região da terra obedecendo a condições peculiares. Assim o crescimento do capitalismo na Inglaterra dependeu de um forte processo de acumulação primitiva, isto é, absorção de trabalho morto e vivo instalado fora do sistema, que passa a assumir então a forma de valor-trabalho. 
No plano da primeira história a mercadoria começa se transformando em dinheiro, mas termina se repondo como mercadoria; por sua vez o capital começa como dinheiro se transformando em mercadorias e retorna como dinheiro aumentado e assim por diante. Na história categorial, as formas categorias são repostas, enquanto na história do vir-a-ser o que foi necessário para a instalação regional do modo de produção não vai ser reposto pelo movimento das formas nem se repetirá em outras ocasiões. Observemos que a história das formas categoriais constitui um sistema simbólico, uma práxis orientada pelo movimento de símbolos. Nãoéisso que Wittgenstein, nas Investigações filosóficas, chama de jogo de linguagem? Além do mais, no parágrafo 50 dessa obra, ele não diferencia o modo do meio de apresentação (Weise und Mittelder Darstellung)? O primeiro diz respeito às regras de um jogo de linguagem, o segundo às condições naturais necessárias ao exercício desse jogo. As regras, por exemplo, que definem os movimentos legítimos do bispo e que fazem parte da gramática desse jogo, não se confundem com condições naturais e sociais assegurando que as peças sejam manipuladas. E não há erro mais comum e mais prolífero do que tomar propriedades dos meios de apresentação como se fossem momentos das regras, da gramática do jogo. Os jogos de linguagem como as categorias da economia burguesa são Gedankenformen e como tais estabelecem regras de condutas que para serem seguidas necessitam obedecer a certos condicionamentos inseridos no mundo. Mas não é por isso que o travejamento do mundo lhes seja anterior.

Teorias científicas podem ser consideradas como jogos de linguagem, investigadas como se formam os signos com as quais elas lidam e como se reportam a realidades que elas mesmas conformam, desde que se levem em conta as experiências por elas controladas. Não é assim, entretanto, que o cientista normalmente lida com elas. Simplesmente toma seus conceitos básicos ligados entre si por relações específicas, geralmente recorrendo a técnicas matemáticas, à procura de um modelo capaz de mostrar como o real está funcionando e quais são as previsões possíveis a partir do sistema simbólico. É possível, como diria Wittgenstein, analisar esse sistema e o que se diz dele, a sua prosa, daquele ponto de vista que privilegia o nascimento de seus significados, mas não é por isso que se estaria fazendo ciência. Fazer ciência não é descrever os jogos de linguagem nos quais ela consiste. Dado um modelo científico e técnico,é possível dizer que isto acontece por esta ou aquela razão, mas não tem sentido dizer que isto tem razão independentemente do quadro científico a partir do qual a pergunta pode ser feita e respondida. Dados os axiomas da aritmética seguemse os teoremas demonstráveis a partir deles, mas sabemos ser possível construir uma expressão aritmética que não pode ser demonstrada nem como verdadeira nem como falsa no sistema já montado. Há 
enunciados da teoria da relatividade que não são compatíveis com enunciados da física quântica. Em biologia noção de mutação implica uma reorganização do código genético inexplicável a partir dele. Estes são alguns exemplos que tomo simplesmente para indicar: primeiro, que as noções de necessidade e a de demonstração variam de sentido conforme a teoria científica em que estão sendo usadas; segundo, que a idéia de razão funciona dentro de determinados limites, vale dizer, a razão é dita de várias maneiras. Com isso estamos nos livrando de racionalidades totalizantes tais como a famosa Zweckrationalität (racionalidade em função de fins dados), ou a razão substantiva e assim por diante. E se ainda for possível pensar o desenvolvimento da ciência e da tecnologia como processo de racionalização do mundo, desde logo é necessário investigar de que ótica isto está valendo. Entender a razão como faculdade da alma depende do que se entende pela unidade do eu transcendental; considerá-la como se estivesse escrevendo atos em busca do bom entendimento não lida com a diferença entre meios e modos de apresentação, o que esconde uma concepção ainda formalista da linguagem. Do ponto de vista dos jogos de linguagem, esses dois caminhos carecem de sentido.

VII.

Levando em conta essas diferenças voltemos a Marx. Ele pretende tanto escrever a ciência do capital como desenvolver a crítica do objeto estudado, estabelecendo uma determinação recíproca entre as duas tarefas. Nesse ponto o título de seu livro é explícito: "O capital: crítica da economia política". Crítica orientada pelo materialismo dialético que, em momentos aparece como método, outros como ontologia ainda ligada aos procedimentos hegelianos e assim por diante. Mas, por ironia da sorte, o primeiro volume d'O capital vem à luz em 1867, quatro anos depois Stanley Jevons publica Theory of political economy, abrindo o caminho para a teoria marginalista, que toma como ponto de partida o valor de uso até então sistematicamente descartado pelas teorias econômicas. Em 1890 Alfred Marshall publica Principles of economics consolidando o novo paradigma. A nova teoria, graças ao refinamento de suas técnicas matemáticas, se mostra cada vez mais eficaz no tratamento de seus modelos descritivos dos mercados e assim termina reduzindo a teoria do valor-trabalho a um momento da história do pensamento econômico. Ainda enquanto se mantinham as tentativas de construir uma economia socialista foi possível pensar os fenômenos econômicos a partir de duas perspectivas: do mainstream neoclássico e do ponto de vista "dialético" seguindo os passos do marxismo. Depois da passagem do socialismo para o capitalismo tornou-se difícil manter essa dualidade. Em conseqüência disso o marxismo desapareceu do foco do pensamento atual, sobrevivendo apenas em algumas ilhas 
isoladas. Estaria, porém, inteiramente morto? Não há hoje, no planeta, uma economia que não se exerça segundo as leis do mercado. Mas poucos ainda acreditam que ele se auto-regule. Que tipo de lei institucionalizada será capaz de regulá-lo, de emprestar-lhe uma racionalidade que não se subordine à racionalidade do capital? No final das contas, o extraordinário crescimento da China atual se faz sob a égide de um socialismo de mercado e a questão do controle dos mercados se tornou extremamente atual. Daí a importância de uma pergunta prévia: o que quer dizer mercado? Um modelo de seu funcionamento seria capaz de responder a essa questão? Não reduziria ele seus objetos a "coisas", a "variáveis" num campo de objetos individualizados, não o colocaria num plano de objetidade peculiar às ciências, que nem semprevem a ser capaz de responder a questões de sentido? É possível entender os jogos de linguagem em que essa palavra "mercado" faça sentido? Desse ponto de vista, creio que as análises de Marx muito podem contribuir para melhor entendimento dessas indagações.

\section{VIII.}

Antes, porém, é preciso entender os meandros e o alcance de sua crítica. Vale a pena salientar que Marx e seus contemporâneos entendiam por ciência algo muito distante do que hoje entendemos por ela. Convém lembrar que nos meados do século XIX o progresso das ciências disparou graças ao aumento espetacular dos recursos teóricos, a um aumento exponencial do número de pesquisadores e dos capitais a elas destinados. Em particular Marx aprovou a revolução nas ciências naturais e sociais provocada por Darwin, que alterou profundamente o modo pelo qual nos situamos frente a frente com a natureza. Sofreu essa influência e, muitas vezes, adere a seu historicismo. Aliás, já na Ideologia alemã apontara a história como paradigma das ciências em geral, embora mais tarde recupere a tese hegeliana das duas historicidades.

No primeiro capítulo d' O capital Marx reproduz basicamente a teoria do valor-trabalho, tal como tinha sido elaborada por Ricardo, mas enlaçada num movimento conceitual inspirado na dialética hegeliana. Nada mais longe, por conseguinte, do que se costuma entender por ciência ontem e hoje. Qual sua principal crítica a Ricardo? Este "não investiga de modo algum o valor segundo sua forma - a forma determinada que o trabalho assume como substância do valor -, mas

[3] Marx, K. Theorien über den Mehrwert. Berlim: Dietz Verlag, 1962, t. 2, p. 163. apenas as magnitudes-valores, as quantidades desse trabalho [...]"3. Mais do que relações funcionais entre valores e quantidade de horas de trabalho, como aliás fazem os cientistas em geral, importa a Marx a forma-valor enquanto trabalho abstrato socialmente necessário posto como substância desse valor. O queentende por essa forma eessa substância? Lembremos que na Fenomenologia do espirito Hegel frisa que a 
substância deve ser tratada como sujeito. O valor não é apenas trabatho, mas ainda pedaço da natureza trabalhada por um processo coletivo, que encontra sua medida num tempo socialmente necessário para produzir objetos como mercadorias. Como esse pedaço de natureza vem a ser valor dotado daquela reflexão que caracteriza o sujeito?

Entre os trobriandeses, objetos são trocáveis somente em determinadas faixas, por exemplo, uma cesta de inhame pode ser trocada por outra de peixe. Desse modo, uma cesta vale outra, mas é impossível trocar uma canoa por peixe ou por inhame, somente por uma mulher. Os objetos não se reduzem a uma mesma medida de valor. Não éo que acontece no mercado em que todos os produtos que ali estão são trocáveis entre si. Essa trocabilidade universal abstrai dos produtos todas as características de sua produção, eles são medidos exclusivamente pelo trabalho morto que incorporaram como se fosse indiferente o trabalhador lidar com este ou aquele objeto. Não se trata, pois, do trabalho vivo na sua variedade, mas daquele trabalho que a sociedade como um todo realizaria para obter os produtos de que necessita. Mas são os indivíduos que agem. Como a diversidade dos atos vivos de trabalho passa a ser medida pelo tempo abstrato e socialmente necessário de trabalho morto inscrito nos produtos? Como se dá efetivamente essa mensuração?

Cada produto enquanto valor de uso é reportado a qualquer outro produto no mercado enquanto expressão de seus valores de troca. O comum a todos esses valores de troca é a substância valor que se exprime no dinheiro. Cada produto possui então um valor, que neste nível é o seu preço. Mas o valor de troca é apenas representado, o dinheiro como equivalente geral é apenas medida a ser aplicada. Isto se torna claro no modo de produção capitalista, quando todos os fatores de produção comparecem com seus preços. O valor, portanto, éregra a ser seguida pelo entrosamento dos atos individuais de trabalho, os quais unicamente confirmam a medida pressuposta por cada um ao chegar ao fim do processo, quando o consumo coletivo comprova o quantum de trabalho social necessário para cumprir a demanda agregada. Notese que os atos produtivos se tornam coletivos conforme suas regras (Gedankenformen diz Marx) sejam de fato exercidas. Mas o que aparece como fato éo produto expresso por seu valor, por seu preço.

A economia neoclássica parte desse fato, não indaga pelo sentido dos atos produtivos; mais ainda, o valor marginal não se reporta à coisa como produto, mas apenas como objeto de consumo. Em geral uma regra científica diz respeito à maneira pela qual vemos e prevemos como certas regularidades naturais acontecem. N' O capital essa relação entre fato e regra (conceito) é muito mais complexa. Parte do fato de que há uma riqueza capitalista apresentando-se como imensa coleção de mercadorias, sendo então a mercadoria individual sua 
[4] Idem. Das Kapital, I, 77. Berlim: Dietz Verlag, 1964 [O capital: crítica da economia política. São Paulo: Abril Cultural, vol. 2, t. 1, p. 71 (Os Economistas), trad.modificada]. forma elementar. Como se estrutura a forma-mercadoria, qual é seu sentido? A partir de suas duas determinações, valor de uso e valor de troca. Sendo em princípio os valores de troca compatíveis entre si, eles apresentam algo em comum que vem a ser a regra que os medem.

Posso trocar um cacho de bananas por $x$ laranjas segundo a utilidade marginal, mas, se preciso consumir laranjas para continuar produzindo bananas para o mercado, a troca de bananas por laranjas deve levar em consideração aquilo que as torna comensuráveis, a regravalor como sua condição de existência. Esses objetos como produtos comensuráveis resultam de um trabalho abstrato medido então pelo tempo socialmente necessário para obtê-los. Ao chegar ao mercado cada produtor trata seu produto como sendo comensurável a todos os outros em virtude de todos terem valor, a substância comum. Essa comensurabilidade é pressuposto da ação, mas sua medida somente se configura quando a ação já tiver sido executada, pois somente assim o tempo gasto se mostrará socialmente necessário. A substância tão-só se configura quando a demanda efetiva vem comprová-la. Como totalidade começa sendo, pois, uma ilusão necessária ao cumprimento da regra. O efetivado, o posto, vem a ser pressuposto e tudo se passa como se a regra platonicamente produzisse seus casos. A forma-mercadoria rebate as características sociais dos trabalhos como se fossem características dos próprios produtos dos trabalhos, como propriedades naturais dessas coisas: a

igualdade dos trabalhos humanos assume a forma material de igual objetidade de valor dos produtos de trabalho, a medida de dispêndio da força de trabalho do homem, por meio de sua duração, assume a forma da grandeza de valor dos produtos de trabalho, finalmente as relações entre os produtores, em que aquelas características sociais de seus trabalhos são ativadas, assume a forma de uma relação social entre os produtos do trabalho4.

Cabe prestar atenção a esse qüiproquó. Primeiro, ao se igualarem os valores das mercadorias A, B..., todas as diferenças dos respectivos trabalhos efetivos foram anuladas, mas de tal maneira que todas elas valem do mesmo modo, apresentam quantidades diversas da mesma substância valor. Segundo, o dispêndio de força de cada ato, medido por sua duração, apresenta-se igualado e rarefeito na relação entre as grandezas dos valores. Terceiro, a relação efetiva dos produtores se apresenta como relação entre produtos dos respectivos trabalhos. Note-se que o travejamento concreto das relações sociais se apresenta então como o movimento de formas categoriais, de sorte que a identidade dos agentes passa a ser determinada segundo o modo pelo qual eles realizam a forma correspondente. Assim sendo, o movimento das formas hegelianas a presenta tão-só a casca dos processos efetivos que, 
todavia, somente são efetivos enquanto se anularem nessa casca. A forma-valoré substância na medida em que se apresenta como relação de coisas nos três níveis em que comparece. A reificação permite que relações sociais da produção mercantil sejam tratadas como coisas, por conseguinte do ponto de vista científico.

Compreende-se o primeiro aspecto da crítica de Marx: ao mostrar como as propriedades definidoras, essenciais, da coisa-mercadoria se imbricam entre si no jogo da diferença e da identidade, termina mostrando que essas propriedades têm sua existência condicionada por certas relações sociais de produção que se exercem sob sua medida. Os atos produtivos para o mercado se apresentam como se fossem relações entre coisas. Se a ciência não for crítica, ela pode se tornar extremamente eficaz, mas não apreende o sentido das ações humanas envolvidas. Pode explicar o funcionamento da economia de vários pontos de vista, inclusive montando modelos de suas crises, mas não mostra o sentido dessas relações, não expõe sua gramática e o significado de suas rupturas. Note-se que cada passagem de uma forma reificada a outra abre a cesura para a crise, a interrupção do processo.É o que já provoca o entesourador que, em vez de cumprir a função mediadora do dinheiro no processo de troca, retém seu curso, conserva em suas mãos uma parte do equivalente geral de todas trocas, causando assim um solavanco no movimento total das mercadorias. E bloqueado o curso da troca por uma crise matriz, não se abre o espaço para a pergunta pelo sentido dessa troca? O que ela querdizer? Dessa pergunta pode resultar uma melhor compreensão da dificuldade, o que permite introduzir novas regras para evitar o percalço. Esse tipo de entesourador desaparece, por exemplo, se a moeda periodicamente perde ovalor. Note-se queesse tipo de crise, cujo perfil acabamos de traçar, ainda não diz nada sobre a economia capitalista real, porquanto apenas respeita à reposição do modo de produção simples de mercadorias, que só pode existir em momentos fugazes do processo econômico.

Observe-se que a crítica não começa do ponto de vista da dominação, da exploração de uma parte por outra, pois esta não existe no modo de produção simples das mercadorias. Cada mercadoria se dá valendo tanto. Um abacaxi vale $R \$ 5,00$, uma caixa de morangos $R \$$ 1,00 e assim por diante. O que há de comum entre produtos tão diferentes? No início a pergunta indaga pelo queé, mas este ser se resolve num processo sui generis de medida, cujo parâmetro inicial depende de uma totalização ilusória. No mercado os agentes atuam como se fossem atores mascarados agindo para fazer valer o papel inscrito em suas máscaras. A crítica desvenda essa reificação, permite melhor entendimento do esquema operatório no qual a troca mercantil se resolve e abre espaço para um controle mais fino do procedimento que o faz ser e o faz explodir em crises. De um lado, a análise da coisa-ação 
passa pela análise do sentido, de outro, a ciência encontra um espaço que explica como os agentes interagem entre si e o significado de seus percalços. A crítica nasce quando o processo de reposição e reflexão emperra ou, para lembrar uma imagem de Wittgenstein, quando essa linguagem não-verbal do mercado e da produção entra em férias.

Ao desvendar a gramática da troca mercantil Marx descobre o sentido das medidas dos valores; por conseguinte, o sentido desses valores, e nele localiza uma inversão sui generis, segundo a qual o medir se torna medido graça a uma totalização idealizada, representa$\mathrm{da}$, embora a todo momento essa estabilidade esteja sendo posta em xeque. Ser livre é controlar a medida de seus atos. Quando se forma uma medida automática, cada agente perde sua liberdade enquanto produtor capaz de levar ao mercado seus produtos. No entanto, ao mesmo tempo, ele se apresenta como proprietário, possuindo direitos sobre o que produz, por conseguinte sendo definido como sujeito jurídico. $O$ agente perde o controle completo de seu ato individual, mas se vê reconhecido como proprietário, sujeito de direitos. Se houver conflitos, no que respeita à medida ou à propriedade dos produtos - é impossível que isto não aconteça num mercado efetivo - , os agentes se prepararam para aceitar um juiz imposto de fora ou eleito por eles mesmos. De fato, não há situação de mercado em que não compareça um juiz. A fissura na relação reificada tanto abre um espaço de dominação como um espaço de liberdade.

Uma relação de troca de mercadorias, já considerando o equivalente geral intermediário, está sob a forma M-D-M-D... Quando se transforma em D-M-D...é toda a intencionalidade do jogo simbólico que se altera. Deixemos de lado os requisitos históricos para que isso aconteça. No plano categorial, gramatical, o capitalista só corre o risco de transformar seu dinheiro em mercadorias se estas consistirem em fatores de produção cujo produto final valha mais do que o dinheiro acumulado inicialmente, isto é, o capital. Daí a pergunta: se todos os fatores de produção estão determinados sob a forma do valor, medidos por conseguinte pelo trabalho morto que incorporaram, de onde vem esse aumento de capital, noutras palavras, de onde vem o lucro? No plano categorial, e exclusivamente nele, provém da diferença entre o valor da força de trabalho e o valor do produto que ela cria. O lucro nasce da transformação da força de trabalho, avaliada pelo valor do trabalho morto nela inscrita, em trabalho vivo criador de novos produtos. Nesse plano, insisto, a forma-lucro advém do mais-valor produzido sob o controle do capital. Mas, no nível das condições de existência desse desdobramento formal, a grandeza do mais-valor depende igualmente da boa vontade ou da resistência do trabalhador.

Vale a pena dar um passo adiante. Numa jornada de trabalho de 12 horas, suponhamos que o trabalhador trabalhe 10 horas para repor o 
valor de todos os fatores de produção, inclusive o valor de sua força de trabalho. Este é chamado trabalho necessário. As outras duas horas correspondem ao mais-trabalho. Ao capitalista interessa aumentar a produtividade do trabalho de tal modo que a mesma quantidade de produto seja produzida, suponhamos em 9 horas, o que aumenta o tempo de mais-trabalho para 3 horas. Isto só pode ser obtido graças ao aumento da produtividade do trabalho, fazendo crescer exponencialmente o valor de seu capital, em princípio diminuindo o valor da força de trabalho. Não é assim que se explica o extraordinário avanço das ciências e das tecnologias durante e depois da Revolução Industrial?

Todo esse processo, entretanto, já que ocorre sob a égide da substância-valor, pressupõe que,embora cada capitalista esteja tudo fazendo para aumentar a produtividade do trabalho por ele empregado, não haja barreiras estruturais que impeçam seus concorrentes de ter acesso às novas tecnologias. Caso contrário, a constituição do valor, daquele comum a qualquervalor de troca, ficaria comprometida. Ora, esse livre trânsito das novas tecnologias fica bloqueado com o monopólio da invenção científica e tecnológica por parte daqueles produtores que se associam com a tecnociência. É evidente que desde logo o capitalista cuida a todo custo para que seu concorrente não tenha acesso àquela tecnologia que lhe está aumentando o mais-trabalho extraído do trabalhador. Mas, depois de um certo tempo, não há como evitar que isso aconteça, pois os segredos são confessados e tecnologias semelhantes são inventadas. A não ser que alguns capitalistas passem a ter, ainda que em rodízio, o monopólio da invenção científica e tecnológica. Passam a ter acesso a novas teorias e novos procedimentos antes que seus concorrentes consigam chegar perto de seu nível de eficiência. Não há dúvida de que isso também é temporário. Sempre é possível que um grupo de inventores geniais lance no mercado um produto incomparável e, enquanto outros não lograrem fazer algo semelhante, chegam a acumular impérios. Mas do ponto de vista categorial, do sentido das formas do modo de produção capitalista, importa que um proprietário qualquer desse monopólio da invenção tenha sempre à disposição novas tecnologias e novos produtos antes que seus concorrentes de fim de linha possam obter tecnologias e produtos equivalentes. $O$ produtor que chega ao mercado está em princípio comparando seu produto como valor de troca a todos os produtos que ali estão, mas na hora da troca efetiva essa comparação não pode ser feita, pois a nova tecnologia não possui medida comum com os outros produtos. Por certo o trabalhador de qualquer ramo opera sob o metro das horas de trabalho, mas para que estas se tornem medidas de valor é preciso que tais horas sejam socialmente necessárias, o que somente se efetiva depois do consumo se mostrar socialmente necessário. Noutras palavras, fica bloqueada a constituição da substância-valor, daquele comum totali- 
zante que percorre todos os valores de troca representados. $O$ mercado se cliva então em várias faixas, o que desde logo coloca a questão: como ele se integra nessas novas condições?

É de notar que com isso o sistema capitalista, entendido como um jogo movimentando partes do mundo natural e social, está semprealterando suas regras, formando um jogo muito parecido com o anterior sem ser todavia idêntico a ele. Marx pressupunha, seguindo uma tradição hegeliana, que essa acumulação de mudanças, de crises, resultasse numa crise tão profunda que o sistema inteiro haveria de ser alterado numa eclosão revolucionária: um novo modo de produção surgiria livre das servidões da divisão social do trabalho, emancipando então a humanidade das antigas formas de opressão. Isto no final do século XIX. Depois disso o capitalismo tem passado por crises profundas, particularmente a autonomia do capital financeiro tem descolado o jogo dos juros da economia real até que o curso dos papéis desabe e seus preços procurem alguma faixa de valor real. Mas a crise revolucionária desapareceu do horizonte, em particular porque as classes mais pobres passaram a consumir a despeito das enormes desigualdades entre países ricos e países pobres. Assim como os capitais não se integram num capital social total, igualmente os setores operários não se integram num trabalhador total. E quando se tentou articular um sistema produtivo fora das incertezas dos mercados, racionalmente orquestrado por um comitê central, nada funcionou no longo prazo. Não está no nosso horizonte atual criar um sistema econômico efetivo dispensando os mecanismos de mercado, com suas invenções e suas crises. Daí a importância da pergunta pelo seu significado, mais densa do que a simples articulação de seu modelo, pois somente assim suas crises terão seus sentidos revelados. Não há dúvida de que existem na teoria econômica vários modelos de crises, mas somente depois de saber o que cada tipo de crise quer dizer é que podemos nos propor a implementar soluções capazes de aumentar o controle de ações humanas que irremediavelmente passam pelos caminhos da alienação, da perda da intenção original que as desencadeiam. E como essas soluções irremediavelmente reclamam controles vindo de fora do mercado, será possível poder avaliar até que ponto são mais ou menos democráticas.

Em qualquer sociedade os trabalhadores ativos produzem mais do que consomem, pois no mínimo há crianças e velhos para sustentar. No modo de produção capitalista, em princípio, esse mais-produto se dá sob a forma de mais-valor. Mas o que as crianças e velhos recebem são valores que foram transformados em preços: o preço da alimentação, da educação, da saúde e assim por diante. E nesse plano não há forma de traduzir esses preços em valor, movimento categorial capaz de desenhar as instituições intermediárias. A distribuição do 
mais-valor se faz então por uma luta em que os atores invocam seus direitos e exercem seus poderes. Isso se generaliza quando as ciências se tornam forças produtivas, quando o monopólio da invenção tecnológica bloqueia a expansão das novas tecnologias. Estas não mais se espraiam como manchas de óleo, mas são conquistadas conforme os atores ocupam posições estratégicas no mercado, nos laboratórios de pesquisa, no Estado. Agora, no plano categorial mais simples, não mais o capital, mas os capitais se repõem mediante lutas envolvendo capitalistas entre si, capitalistas e trabalhadores e trabalhadores entre si. Lutas que podem chegar ao limite, à exclusão do outro do sistema capitalista, vale dizer, luta política no sentido hobbesiano da palavra, confronto de aliados e adversários.

IX.

O que procurei mostrar? Que a história categorial do modo de produção capitalista, sua racionalidade, à medida que se especifica, dissolve suas categorias, impedindo que elas sejam aplicadas como regras científicas. Mas se demonstrar sua verdade se torna impossível, não é por isso que perdem seu sentido. Continuam a exibir condições de significabilidade de certas ações coletivas que se podem mostrar efetivas ou não. Não vejo como a teoria do valor-trabalho tenha alguma utilidade para o cientista a não ser que ele seja igualmente crítico, procure entender o sentido das ações que se efetivam no metabolismo que os seres humanos mantêm entre si tendo como mediadores os produtos de seus trabalhos.

Separada das ciências, no que se resolve essa crítica? Se ela tem como núcleo o problema da reificação, não é por isso que me vejo obrigado a seguir os passos de Georg Lukács e contra ela erguer a bandeira da consciência de classe. Mas alguma coisa me sobrou do projeto de uma ontologia do social se a ontologia estiver escrita na gramática. Prefiro mostrar que a fibrilação das categorias da lógica do capital, tal como foi analisada por Marx, nos conduz a uma política cujo exercício irá mapear as classes em luta. Ao situar o valor dessas categorias no plano dos sentidos, não posso imaginar que a crítica se resolva numa teoria alternativa à teoria tradicional. Falharam as tentativas de uma economia marxista, assim como serão inúteis, creio eu, todos os esforços pretendendo mostrar a validade empírica da teoria do valortrabalho. Já que ela estabelece os princípios da gramática do capital, situa-se no mesmo nível daquela da gramática da língua portuguesa, francesa ou inglesa. Falamos segundo suas leis, assim como os mercados regulam à sua maneira os atos de trabalho, isto é, o metabolismo que os seres humanos mantêm entre si e com a natureza. Suas leis simplesmente permitem que as pessoas se entendam e se mostrem nesse entendimento, mas apenas nesse nível. No caso do capital, o 
entendimento e o desentendimento se mostram na configuração de amigos e adversários na luta pela produção e distribuição da riqueza, antes das nações, agora do planeta.

X.

À medida que a crítica marxiana se descaracterizou como ciência, a crítica do capital foi sendo substituída por uma crítica da modernidade. Nesta linha de pensar, Max Weber tem sido a influência dominante. Seria porque sua sociologia já é hermenêutica? Seja como for, aos poucos a crítica do capital se conformou como crítica das relações sociais do ponto de vista de suas racionalidades. Não no nível em que elas se exercem, mas projetadas nos eixos da racionalidade em vista dos fins dados e da racionalidade substantiva, capaz de pensar a si mesma. O velho fantasma da faculdade da razão reaparece sob as formas mais diversas, precisamente quando a crise do formalismo lógico coloca em xeque a própria idéia de uma razão unitária. Para tanto, alguns retiram do trabalho seu caráter interativo, como seo ato de trabalho pudesse se exercer em sociedade sem que regras de propriedade assegurassem ao produtor que seu produto não fosse devorado por outrem. No entanto, o mais surpreendente é que a crítica da razão instrumental, em vez de se ater aos pontos em que esta razão patina, passa a ser projetada tendo no horizonte uma sociedade sem classes, sem fissuras intrínsecas, como se a idéia reguladora do reino dos fins pudesse encarnar-se na terra. Marx pensou que isso seria possível porque tomou um ponto existente na história, a classe operária que, sofrendo a irrazão e violência do capital, se emanciparia criando uma nova racionalidade e exercendo uma violência emancipatória. Sem esse ponto de apoio no nível dos fatos, a idéia de emancipação se torna reguladora, dependente de um conceito unitário de razão e incapaz de reconhecer a violência de certos processos políticos. Pensar os conflitos do mundo contemporâneo do ponto de vista da emancipação exala o perfume do misticismo leigo. No fundo, no lugar da idéia marxiana de que a política, graças à revolução, seria substituída pela administração racional das coisas, coloca-se uma política do bom entendimento na paz do Senhor. Mas se no nível dos processos capitalistas globalizados se evidencia a violência de perversas estratégias de conquista de mercados, inclusive do mercado de trabalho, que razão e forças políticas serão capazes de contê-las? Não é aqui que o salto há de ser dado?

XI.

Volto a meus antigos demônios. Vivemos numa sociedade de consumo. Em que medida numa sociedade de consumo capitalista? Examinemos brevemente apenas alguns pontos dessa questão. $O$ fetichismo se configura nos primeiros passos do desdobramento da forma-mer- 
cadoria. Num ponto em que o desdobramento das formas-categorias do capital já estão muito desenvolvidas vamos encontrá-lo sob as três formas em que se apresenta o mais-valor: lucro, renda e salário. Cada um se dá como o produto natural do capital, da propriedade da terra, do trabalho. Mas é nos juros que encontramos, no seu extremo, a forma-fetiche da mercadoria. As ações e os sujeitos surgem como moléculas dotadas de movimento browniano, erráticas mas compondo a regularidade das catástrofes. Os indivíduos mantêm a propriedade de seus títulos, mas ela é apenas formal, porquanto o valor desses títulos depende de movimentos cujas causas seescondem nos meandros dos processos produtivos e distributivos. "É a produção privada", escreve Marx, "sem o controle da propriedade privada"s.

Essa reviravolta, essa reflexão formal se enriquece e se diversifica no consumo. Cada modo de produção conforma seu próprio consumo e abre os espaços de controle e descontroles dos impulsos, carências e previsões que o movem. Antes de tudo, porém, nos interessa esse consumo que se converte na condição de subsistência da economia como um todo, que os agentes necessitam realizar para que a economia global tenha sucesso, conserve o sistema na sua marcha indispensável em busca do crescimento. Crescimento crescente não se traduz, contudo, em consumo erraticamente crescente, mas em demanda que não deve ultrapassar as condições da oferta de produtos para que não se desencadeiem reações inflacionárias. Por certo a atividade econômica como um todo desemboca no consumo, mas cada modo tem sua forma. O consumo capitalista precisa estar sob relativo controle dos bancos centrais e de organismos internacionais de crédito e de negociação do comércio. Consumo, além do mais, que desenha formas de vida e que está levando aos limites a exploração dos recursos naturais e humanos. Se o capital tão-só existe crescendo, entrando em crise, destruindo forças produtivas e renascendo, o nível e as formas de consumo são o seu termômetro, por conseguinte imbricando demanda efetiva, competição capitalista e as políticas públicas.

Toda essa luta e essa engenharia afetam a essência do objeto de consumo e do consumidor. O primeiro corre o risco de ter suspensa sua natureza de coisa. Esta se apresenta para nós nos seus múltiplos perfis, um depois do outro, num enriquecimento contínuo que não tem fim; liga-se a fatos, estes fatos se juntam ou se dissolvem desenhando um mundo. Mas cada vez mais cresce à nossa volta objetos de consumo descartáveis. Ainda no século XIX as pessoas se cercavam de poucos objetos de consumo: os alimentos duravam pouco a não ser aqueles de luxo. Hoje em dia estamos cercados de objetos transitórios ou descartáveis. Até mesmo as capitais mais modernas estão cercadas de habitações provisórias, o conforto demanda miríades de objetos que hoje estão ali e amanhã desaparecem. 
A coisa está ali, mas outra pode vir a substituí-la, seja a mesma maçã sempre disponível no mercado, seja a nectarina que cumpre função semelhante. Sua presença está associada a seu valor, por conseguinte a outra de igual valor. Mas não de igual marca ou de prestígio. Mesmo quando os valores são semelhantes, a grife traz ao consumo uma diferença, uma forma mais forte de socialização. Por certo o modo de comer já indica competição de classe, mas a marca de uma roupa, cada vez mais estampada no seu exterior, distingue justifica elevação de preço e prestígio elevado.

Assim sendo a coisa se torna descartável no meio da abundância, ou coisas são postas à margem à medida que suas marcas se tornam dessuetas. A tudo isso se soma a obsolescência programada dos instrumentos. Este meu computador logo precisará ser trocado porque não mais me servirá para receber e enviar e-mails, navegar na internete assim por diante. É uma coisa que está diante de mim, mas tem futuro determinado. Mas ele não morre como um ser vivo, que esgota os arranjos de seus órgãos, vai ser encostado porque deixa de seencaixar na segunda natureza de um sistema produtivo que só persiste se crescer.

Por isso tende a se apresentar como uma imagem. Não aquela imagem que vejo na tela e que vem a ser a realidade de meu texto, mas a presença de um monitor que já não é de plasma, que ocupa um espaço desproporcional às suas funções, que contrasta com a televisão de última geração espreitando ao lado. Não estou pensando a imagem no sentido dos empiristas, que a resolvem na presença amortecida da coisa percebida, mas num sentido quase fenomenológico, algo posto por uma intencionalidade particular, por certo não da consciência, mas de nossas ações coletivas.

Vivemos rodeados de coisas cuja coisidade é bloqueada pela trama das relações sociais do consumo capitalista. De modo semelhante, vivemos cercados de sujeitos cuja subjetividade está posta entre parênteses, porque devem funcionar antes de tudo segundo seus papéis: de amigo, vizinho, colega de trabalho, concorrente do emprego e assim por diante - a não ser quando com este ou aquele mergulhamos nos meandros da intimidade. É como se vivêssemos num palco grego, cada um de nós cumprindo ações determinadas por nossas máscaras, mas que são de cera e se derretem ao calor do sol. Nesse derretimento cada um tenta alguns minutos de originalidade, uma nova relação com o outro, que se perde na medida em que o outro também derrete. Não é por isso, creio eu, que vivemos numa sociedade do espetáculo, como quer Guy Debord. Porquanto o espetáculo encena um sentido, mesmo quando quer mostrar a falta de sentido, à espera daquele Godot que nunca aparece. Ao contrário, cada vez mais se impõe a falta de sentido da vida cotidiana, o desfazimento dos horizontes, a precariedade do cotidiano. E a fuga no consumo, no transitório de uma novidade. Que 
certeza pode trazer, então, o mundo da vida? Como as estruturas perduráveis do entendimento podem se estabilizar nessa transitoriedade do consumindo-se?

Notável é que as imagens constituem um mundo bloqueado. Em 1940, Jean-Paul Sartre, reformando um texto anterior sobre a imaginação, escreve L'imaginaire, psychologie phénoménologique, aprofundando a nova concepção de imagem desenvolvida por Husserl. Não considera a imagem apenas como presença enfraquecida da coisa, pois ela demanda um ato especial de consciência. Esse ato, porém, não é tético, não coloca a coisa como existente, tem sua realidade posta entre parênteses. Não temos consciência da imagem, mas do objeto na imagem, independentemente de sua existência. Sob esse aspecto o mundo imaginário e o mundo real são constituídos pelos mesmos objetos, mas varia o modo pelo qual estão agrupados e são interpretados.

Para poder imaginar, não basta que a consciência possa ultrapassar o real constituindo-o como mundo. Mas essa ultrapassagem não pode operarse de qualquermaneira, e aliberdade da consciência não pode serconfundida como arbitrário. Pois uma imagem não é um mundo-negado, puramente e simplesmente, ésempre o mundo negado de um certo ponto de vista, precisamente aquele que permite pôr a ausência ou a inexistência de tal objeto que será apresentado "em imagem". A posição arbitrária do real como mundo nãofaráao mesmo tempo aparecero centauro como objeto real. Para que o centauro apareça como irreal é necessário precisamente que o mundo seja apreendido como mundo-onde-o-centauro-não-é, e isso somente pode se produzir se diferentes motivações levaram a consciência a apreender o mundo como sendo precisamente tal que o centauro nele não tenha lugar 6 .

O caráter intermediário da imagem entre a percepção e o conceito permite que se atribua a ela papel relevante na costura do mundo, seja da perspectiva mais idealista, como a de Fichte, seja daqueles que se insurgem contra a filosofia da representação para realçar o silêncio e a multiplicidade diferencial do sensível, como Gilles Deleuze. Para combater a concepção kantiana da coisa em si, Fichte atribuirá à imaginação transcendental uma função constitutiva ainda maior do que aquela postulada por Kant: não é apenas responsável pelo esquema que empresta às categorias seu lado real, mas se confunde com a intuição intelectual. Se para Kant as categorias, formas de pensamento, necessitam do trabalho da imaginação para conformar o real, para Fichte as categorias e os objetos nascem no terreno da imaginação transcendental.

Notável é que dois séculos depois a imaginação assumirá o mesmo papel fundante com os filósofos pós-fenomenólogos de Paris. Logo no início de Différence et répétition Deleuze afirma sua posição media-
[6] Sartre, Jean-Paul. L'imaginaire, psychologie phénoménologique de l'imagination. Paris: Gallimard,1948, p. 234 . 
[7] Deleuze,G.Différence et répétition. Paris: PUF, 1968, pp.3-4. na: "Nem particularidades empíricas, nem universal abstrato: Cogito para um eu dissolvido. Cremos num mundo onde as individualizações são impessoais; e as singularidades, pré-individuais: o esplendor do 'a gente' [on]"7. Mas isso significa o silêncio do sensível, procurar exterioridades que se excedem, transformando assim o real num mil folhas coloridas. Se o pensar carrega uma imagem é importante procurar o pensamento sem imagem, capaz de ressaltar no real unidades do tipo do rizoma, dessas raízes que, em vez de possuírem uma forma arborescente, se ligam em tubérculos, em direções indefinidas. A raiz do gengibre é um bom exemplo. Cabe notar, entretanto, que dessas raízes nascem caules, pontos que se individualizam sem um princípio definido. O sensível se reduz então a uma multiplicidade sem unidades formadas, conformando-se em dobras, pregas, sem formar um sistema, sem atravessar o caos criador, dispondo apenas de estruturas extremamente dúcteis. E o mundo é pensado então como fluxo emanando de um transcendental composto de singularidades pré-individuais. Os subjéteis (superjets) e os objéteis (objetiles) se distinguem apenas aparentemente uns dos outros.

Essas breves lembranças de Fichte e de Deleuze nos servem apenas para sugerir que tanto uma filosofia da consciência que se ergue à reflexão do eu-não-eu quanto uma filosofia da diferença e da repetição concebem a imagem sem que nela se detectem seus traços constitutivos. Num traçado vejo uma pessoa, mas também vejo essa figura como um traçado. Diferença aliás da qual tomo consciência examinando a gramática, os jogos de linguagem nos quais "ver" adquire sentido. $\mathrm{Na}$ imagem o ver e o ver como estão intimamente ligados de tal modo que ora vejo o traçado, ora vejo o objeto, isto é o rosto referido. Mas essa mudança, que se torna paradigmática nas figuras ambíguas como aquela do pato/lebre, implica que se o rosto vem a ser uma presença ausente, então o traçado se torna ausente. Em contrapartida, se o traçado se torna presente, o rosto se esconde. É de notar que no primeiro caso a presença é do modo de apresentação do jogo de linguagem e a ausência de seu meio; no segundo caso, a presença é do meio enquanto a ausência é do modo. Ignorando essa dualidade do signo, por conseguinte da imagem sempre que ela vem a ser significante, a filosofia da consciência ou a da diferença traçam o mesmo caminho linear do sujeito ao objeto e vice-versa. Assim perdem as duas diferentes formas de inserção no mundo. Os modos de apresentação apresentam estados de coisa possíveis de um mundo. Os meios de apresentação já estão no mundo e suas figuras precisam estar desenhadas por uma imagem do mundo, pois só assim asseguram suas identidades. Mundo apresentado pela representação, imagem do mundo pressuposta para que este primeiro mundo tenha sentido. 
Tentando me livrar das arapucas armadas pela filosofia da consciência, estou procurando descobrir práticas sociais que suspendam a posição do mundo, que fazem com que ele nos apareça indiferente, passagem que não leva a lugar nenhum. De certo modo, o consumo capitalista consome o mundo, de tal modo que nele não mais encontramos nosso lugar. Na lógica do capital não cabe a idéia de mundo, ela não indica como os acontecimentos se totalizam. Pelo contrário, estamos tentando mostrar que a lógica do consumo capitalista não repõe o produto como coisa e, assim, o retira do mundo. No entanto, por trás dessa suspensão, se coloca uma imagem de mundo pressuposta: a maioria dos objetos são substituíveis e passíveis de reposição.

Horkheimer, em Teoria tradicional e teoria crítica, afirma que, ao reconhecerem o modo da economia vigente e o todo nele baseado como produto do trabalho humano - assim como a humanidade se organiza na época atual - os sujeitos do pensamento crítico se identificam com esse todo e o compreendem como vontade e razão, como seu mundo. No entanto, ao descobrirem que a sociedade se compara com processos naturais extra-humanos, mecanismos opressivos que escapam de uma vontade unitária autoconsciente, eles descobrem que esse mundo não é o deles mas do capital ${ }^{8}$. Em vez do mundo como vontade e representação, diria esse autor, o mundo totalizado pelo trabalho e pelo capital. Mas essa explicação supõe, primeiro, que o capital, se desenvolvendo, venha a encontrar uma totalidade superior, mesmo que Horkheimer não aceite o conceito marxiano de capital social total. Ora, essa totalização mediante a coletivização dos atos de trabalho me parece impossível depois da transformação da tecnociência em força produtiva. Em vez de um único mercado de trabalho, existem vários deles. Segundo, que se a práxis põe o mundo, ela encontra no trabalho sua forma elementar. Mas, pergunto, que trabalho, sob que modo de produção, sob que forma de interação produtiva? Quero ser claro, para mim a práxis põe o mundo assim como pode suspender sua mundanidade. Não é isso que acontece com o consumo capitalista? Ele assume uma posição não-tética, contraditória, joga os produtos para o mundo das imagens, que finalmente não é mundo.

Para finalizar, uma última observação. Esse mundo do não-lugar, da imagem, é terreno propício para o camaleão da política, que como sempre se move antes de tudo no mundo das aparências. Não é a partir das demandas de consumo que as políticas contemporâneas se organizam? Mas também perdendo o sentido do mundo, de certo modo suspendendo a alteridade que sempre a nutre, fazendo de conta que ela pode funcionar sem um controle, esperamos democrático, dos funcionamentos dos mercados. A liberdade que os mercados demandam como pressuposto se traduz na necessidade de seu controle para que eles mesmos voltem a funcionar criando algum sentido para o sistema
[8] Ver Horkheimer, Max. “Teoria tradicional e teoria crítica". In: Benjamin, Horkheimer, Adorno e Habermas. Textos escolhidos. São Paulo: Abril Cultural, 1980 [1937], p. 138 (Os Pensadores). 
Recebido para publicação

em 15 de outubro de 2008.

\section{NOVOS ESTUDOS}

CEBRAP

82 , novembro 2008

pp. $69-95$ produtivo como um todo. Mas este só terá sentido se os consumidores forem justamente aquinhoados. Se a questão da justiça já se coloca no nível da troca das mercadorias, também nesse nível primordial, no qual se dão os primeiros passos da reificação, já se coloca a questão da liberdade. No jogo de linguagem em que o capital tem sentido, justiça e liberdade são faces da mesma moeda.

JOSÉ ARTHUR GIANNOTTI é professor aposentado da USP e pesquisador do Cebrap. 